\title{
The Research on the Voice and Silence Behaviours of Iranian and Turkish Employees According to Their Demographic Characteristics
}

\author{
Iranlı ve Türk Çalışanların Demografik Özelliklere Göre Seslilik ve Sessizlik \\ Davranışları Üzerine Bir Araştırma
}

Beliz ÜLGEN ${ }^{1}$

Mehmet SAĞLAM ${ }^{2}$

Sahar Mohammadi BAZARGANi ${ }^{3}$ https://orcid.org/0000-0002-7589-6812

https://orcid.org/0000-0002-1909-4284

https://orcid.org/0000-0003-0179-5899

\begin{abstract}
The aim of this study was to present how employees' voice and silence behaviour differ according to demographic characteristics. Two different sample was used as Iranian and Turkish. 160 surveys were distributed for both samples. 123 survey were usable for Iranian sample and 149 surveys were usable for Turkish sample in various sectors. The data were collected using by a questionnaire form and analysed with the statistical program SPSS. The scale for employee voice and silence was adapted from Dyne et al. (2003), including 30 items and six factors. Explanatory factor analysis was used to determine the scale factor structure. Then alpha coefficients were determined for scale reliability. In order to determine the significant difference of employee voice and silence behaviour according to demographic characteristics, a t-test and Anova test were employed. Significant differences were found for employee voice and silence across demographic characteristics on both Iranian and Turkish sample. The similarities and differences between the employees were compared in terms of these two countries.
\end{abstract}

Keywords: Employee voice, Employee silence, Iranian Employees, Turkish Employees, Demographic Characteristics.

\section{ÖZET}

Bu çalışmanın amacı, çalışanların seslilik ve sessizlik davranışlarının demografik özelliklere göre nasıl değiştiğini ortaya koymaktır. İran ve Türkiye olmak üzere iki farklı örneklem kullanılmıştır. Her iki örneklem için de katılımcılara 160 anket dağıtıımıştır. Çeşitli sektör katılımcılarından, İran örneklemi için 123, Türkiye örneklemi için ise 149 kullanılanıbilir anket elde edilmiştir. Veriler anket formu kullanılarak toplanmış ve SPSS istatistik programı ile analiz edilmiştir. Çalışan sesliliği ve sessizliği ölçümlemek için Dyne, vd., (2003), tarafından geliştirilen, 30 madde ve altı faktörden oluşan ölçek kullanılmıştır. Ölçek faktör yapısı belirlenmesi için açıklayıcı faktör analizi kullanılmıştır. Daha sonra ölçek güvenilirliği için alfa katsayıları belirlenmiştir. Çalışan seslilik ve sessizlik davranışlarının demografik özelliklere göre anlamlı farklılığını belirlemek için t testi ve Anova testi uygulanmıştır. Hem İran hem de Türkiye örnekleminde demografik özellikler arasında çalışanın sesliliği ve sessizliği davranışları açısından önemli farklılıklar bulunmuştur. Çalışanlar arasındaki benzerlik ve farklılıklar bu iki ülke açısından karşılaştırılmıştır.

Anahtar Kelimeler: Çalışan sesliliği, Çalışan sessizliği, İranlı çalışanlar, Türk çalışanlar, demografik özellikler

'Prof. Dr, Istanbul Commerce University/Faculty of Business/Department of Business Administration, bulgen@ticaret. edu.tr.

${ }^{2}$ Res. Asst, Istanbul Commerce University/Faculty of Business/Department of Business Administration, msaglam@ticaret.edu.tr.

${ }^{3} \mathrm{PhD}$. Student, Istanbul Commerce University/Social Science Institute/Business Doctoral Program, 


\section{Introduction}

In today's business environment the rapid changes, severe and complex competition conditions require that businesses to evaluate their management practices frequently and to make necessary changes in direction of participative management.

Employees' ideas, suggestions or criticisms are so valuable for the continuous improvement of organizations (Hsiung, 2012). Their to voice can be recognized as constructive and strategic communication instrument for organizational effectiveness, high quality decisions and competitive advantage (Miles \& Muuka, 2011). But in some situations employees prefer to be in silence or withold their ideas, knowledge or suggestions. Although employee voice and silence are seem to be different from each other, actually they are so interrelated terms and have equivalent importance in organizations (Moaşa, 2013).

In the first part of this article employee voice and silence are discussed and in the second part a research is placed which is conducted in Iran and Turkey to investigate the employees' voice and silence tendencies.

\section{Literature Review on Employee Silence}

Human resource as an important assess in organizations plays significant role in intensive competition through participation in sharing opinions and beliefs straightly without fear and deciding as well to improve the organization. Neglecting provided ideas or creating an atmosphere of fear and lack of impressive interactions in organization can be lead to withholding employees concerns and notions and being responsibility about solving organization problems and improvements which were defined by Morrison and Milliken (2000) as "employee silence".

Employee silence can be defined as censorship, quieting, ghettoization, suppression, exclusion, marginalization trivialization and other forms of discounting (Nafei, 2016, p.101). This idea has expressed in an elegant way in a Nigerian proverb "Silence is talk too" (Greenberg and Edwards, 2009). From the point of organizations silence can influence both organizations and employees meanly. Employee Silence occasions unpleasant moods like dissatisfaction, cynisizm, lack of communication and stress (Nafei, 2016). In other words, if voice is refrained proficiency and employee's mentality may be substantially offended. Meanwhile, there is proofs expressing that voice suppressed in organizations are mostly uncertain to participate in voice, especially when the content of voice could be received by audience negatively (Morrison, 2014).

These two terms were studied from the point of justice theory during the 1980's . Justice and voice performance issues were among the most central topics studied (Bagheri et al., 2012). It is possible to say that the concept of justice was first led by authors such as Homans (1961), Adams (1965), Walster et al., (1973) (Greenberg, 1987, p.9). Adams's Theory of Justice (1965) is defined as the determination of whether a person perceives his / her own gains and contributions in a certain ratio with the acquisition and contribution of another individual, which he / she cites, and whether he / she perceives an injustice as a result of these evaluations (Greenberg, 1990, p.400).

While the perception of justice in organizations leads to positive behaviors; The perception of injustice can cause some negative behaviors such as the silence of the employees who make it difficult for the organizations to reach their goals.

In the 1990's, studies followed researches on voice mechanisms and around the year 2000 surveys started to focus on derivatives of "climate of silence" (Bogosian, 2012). Theorematic interaction in organizations requires multiple functions of silence and voice. Engagement in voice increases employee perceptions of organizational policies and procedures, manners and distinguish positions and be aware of rules to participate in the game (McGowan, 2003). According to Rezabeygil and Almasi (2014), silence behaviour states not speaking situation and voice behaviour states speaking about the existing issues and events in organizations. The difference between these terms is not in speaking but in motivational factors of individuals who are silent.

\subsection{Employee Silence Factors}

There are various notions about the parameters cause employee silence (Schechtman, 2008); support of silence by the top management and supervisor, fear based on authority, lack of communication opportunities and employees's fear about the negative reactions of management (Brinsfield et al., 2009 retrieved from Nafei, 2016, p.103).

Richard (2003) states the narrow conceptions of ethical responsibility, lack of organizational political skills, fear, implicated friends, embarrassment, lack of opportunity for voice as possible reasons for employee silence. 
The results of the research managed by Morrison and Milliken's (2000) points that silence in organizations depends on a fear which is caused by negative feedback of management and their implicit beliefs about employees. These results, as in management beliefs, compose disruptive emotions of anger and fear in the organization, infusing silence by its members (Slade, 2008).

\subsection{Types of Employee Silence}

Dyne et al. (2003) classified employee's voice, silence and their behavior towards them in three types. In the model, employees demonstrate these mood as like in passivity, conservative and active moods (Afkhami \& Mehrabanfar, 2015). In passivity mood employees believe that their thoughts can not create any utility for the organizations and most of them are influenced extremely by the authority. In conservative mood employees hesitate to share their opinions with others because of fear and self protection. Lastly in active mood employees express their opinions and thoughts recklessly.

Academics have described employee silence in three different forms based on employee behaviours (Pinder \& Harlos 2001; Dyne et al., 2003; Briensfield 2009; Perlow \& Repening; 2009) Acquiescent Silence, Defensive Silence, Pro-social Silence.

\subsubsection{Acquiescent Silence}

This type of silence is a passive behavior more than active. This type of silence reflects the employees' feeling unable to change the current situations or speak up much so they are not willing to be in organizational development activities (Karacaoğlu \& Cingöz, 2008).

With reference to Pinder and Harlos (2001) and Dyne et al. (2003), acquiescent silence defined as " information, withholding relevant opinions, or ideas, based on resignation". Employees who distinguish this manner of silence accept existing situation where they work and are not eager to talk or to try to modify their current condition, believing that they hold little influence to change that (Pacheco et al., 2015).

\subsubsection{Defensive Silence}

This silence behaviour is rooted from the personal fear of employees to declare their opinions or thoughts. The term can be named by quiescent silence which is a kind of silence that points deliberate negligence (Pinder \& Harlos, 2001).
Defensive silence includes withholding information on problems based on fear that expression of opinions is individually risky, is eliminating facts about troubles that should be corrected in order to protect the self (Dyne et al., 2003).

\subsubsection{ProSocial Silence}

Nafei (2016) declares prosocial silence is keeping organizational information for caring the others utility in organizations. Pro-Social silence is a voluntary and pro-active behaviour showed by the employees who desire to help to others or share their responsibilities (Podkasoff et al., 2000). This type of silence includes cooperation, motivation, the feeling of altruism (Dyne et al., 2003) and conscious decision making.

\section{The Literature Review on Employee Voice}

Albert Hirschman's (1970) treatise, "Exit, Voice and Loyalty" is the milestone research about the employee voice (Ashford, Sutcliffe \& Christianson, 2009). In his study he defined voice from the point of marketing (Miles \& Muuka, 2011). Customer exit states the the loss of customers depending on their dissatisfaction about product or service quality or some lapses in any process of the organization. Customer voice, includes their criticms or comments on product or service. The voice may reflect their satisfaction or dissatisfaction. Customer loyalty defines the customers' retention and the continuity of their relationship with the organization (Gorden, 1988). If they feel their voice is cared by the organization and has a meaningful influence on organizational issues, this situation improve their loyalty feeling and these loyal people are mostly prefer to use voice to modify the actual situation or prefer to wait patiently until the conditions get better (Vangel, 2011).

According to Rusbult et al. (1988) the concept of exist does not mention only quitting job, it also indicates the process of searching a new job and scrutinising the quitting decision. Therefore, exit can be occured by the combination of psychological tendency and behavioral reaction about any discontentedness (Naus et al., 2007). Hirschman defines that making a choice between exit and voice related with oneself's loyalty to the organization and in case of high loyalty propensity of voice will be over exit (Garner \& Garner, 2011).

\subsection{Employee Voice Factors}

Dundon et al. (2004: 1152) voice can be ocurred in four diverse forms such as; (Budd et al., 2010). 
- $\quad$ sign of individual dissatisfaction.

- collective reaction to prevent the pluralistic interest against any inappropriate implementation of management (eg. works councils, unions, joint labor-management consultation committees (Kim et al., 2010), etc.).

- core instrument to improve effectiveness of decision making and management involvement processes in the organizations.

- $\quad$ a bridge between employee and employer to realize mutuality of interest by considering ethical, fair and democratic values in the workplace.

\subsection{Types of Employee Voice}

Voice has widespread usage in many organizational issues as like silence (Dyne et al., 2003) and includes three types which have different effect on management.

\subsubsection{Acquiescent Voice}

Acquiescent voice is a passive and disengaged behaviour that it results in statements of conciliation and support based on resignation (Vangel, 2011) and low self-efficacy to influence any valuable change. Acquisent voice can be explained by two examples. One of them is Abilene Paradoks. The other is Pluralistic Ignorance (Dyne et al., 2003).

Dr. Jerry Harvey introduced this concept in his book "The Abilene Paradox and Other Meditations on Management" and gave detailed information about the Abilene Paradox over the parable that he lived (Harvey, 1988). The parable begins with an unwanted trip of Harvey and his family members from Texas to drive Abilene for dinner on a hot day by a car that had a non functioning AC. The important point in this trip decision, none of the family members even the person who suggested this trip were really willing to go. They approved this suggestion thinking that the others wanted this trip and held off from voicing their own thought (Daft \& Lane, 2008). The main theme of Abilene Paradox emphasizes the avoidance of group members from telling the truth in order to agree with others and to make them happy (Launius, 1988).

Pluralistic ignorance was developed by Floyd Allport and his student Daniel Kantz in 1931 (Bjerring et al.,2014). He saw this concept unwarrented and confused reactions of how other people think and feel on different matters (Shamir \& Shamir, 1997). It indicates the dissonance between attitude and behavior. O'Gor- man defines pluralistic ignorance as "a situation in which individuals hold unwarrented assumptions about the thoughts, feelings and behaviour of other people and it's not ignorance in the ordinary sense of not knowing " (Johnson-Cartee, 2005, p.36).

People explicitly participate to others' thoughts or confirm their decisions even though they do not indigenise those thoughts or decisions. They behave in this manner because of the social pressure (Prentice \& Miller, 1993) or their worries about being excluded, rejected, or incompatible person in a group (Shelton, \& Richeson, 2005).

In the literature many examples are placed to explain the meaning of pluralistic ignorance. One of them is classroom case. In this case, a teacher presents some difficult materials in the classroom and after presentation asks the students whether they have any question. Despite most of them does not exactly explain the materials, they hesitate to ask question because they believe that the materials are easy for others except oneself so they don't want to be seem as stupid or the only one who did not understand those materials in front of their classmates (Zanna, 1996; Bjerring et al., 2014; Prentice \& Miller, 1993).

\subsubsection{ProSocial Voice}

ProSocial Voice is a kind of proactive, voluntary and other-oriented behavior that is shown as expressing solutions, sharing experiences or suggesting constructive thoughts about work related issues by considering the others' benefit and this behaviour is shown by employees' will instead of the organization's this fundamental and upward-directed communication behaviour (Moeidh et al., 2015) is shown by employees' will instead of the organization's requirement (Dyne et al., 2003). Pro-social Voice also includes asserting of many useful ideas and suggestions by taking into account the whole organization's interests in any process of change. This discretionary behaviour provides positive, improving and beneficial contributions to organization based on cooperative motives, majority interests and alturism (Ehtiyar \& Yanardağ, 2008). So it can be seem as a form of citizenship behavior (LePine \& Dyne, 2001).

\subsubsection{Defensive Voice}

Defensive voice is a self-protective behavior used to express thoughts or knowledge to protect one's self interests from feared and undesired consequences (Dyne et al., 2003; Turgut \& Agun, 2016). 
In organizations, defensive voice includes employees' criticism, complaints on work-related ideas, information or opinions and blaming others or providing justifications for one's actions to reduce personal threats. In this point of view, defensive voice based on self interest rather than the benefit of organizations or the others (Lee et al., 2014; Ellis \& Dyne, 2009). Managers may realise the defensive voice of employees by caring the expressions, stresses and tones in their verbal messages, non verbal statements, and the direction of their voice whether it's based their based the interest of oneself or majority (Lee et al., 2014).

\section{Research Questions}

Our study examines employee voice and silence behaviors in terms of demographic features within the context of developing economies. Earlier studies on employee voice behavior have been associated with economic and employment contexts (Menendez \& Lucio, 2014; Wilkinson et al., 2013).

In the literature, it has been concluded that voice behaviour has been adopted in developed countries, especially in term of socio-economic development (Gomez et al., 2010; Wilkinson et al., 2013, Soltani et al., 2017). However, in some countries, such as Iran, due to hierarchical authority, obedience to the rules, and fear, employees are expected to prevent from reporting nonconformities and exhibit silence behavior. In some studies, it has been demonstrated that different types of employee voice and silence behaviours were revealed for different social, economic development and institutional evolution stages of countries (Wood, 2010, Soltani et al., 2017).

Turkey and Iran are some similar in terms of Hofstede's cultural dimensions. The high power distance of managers is followed by autocratic leadership and a strong directive approach. Individualism is only reinforced because the interests of the individual are always prioritized according to the interests of the group and the organization. The strong desire to avoid uncertainty also plays a role as a distinctive feature of the culture of these two countries (Hofstede, 2001). Because of that, employees are expected to exhibit different behaviors in terms of the culture which they have.

Also, the employees can be exhibit voice or silence behavior due to their moral and social values. Different socio-economic and demographic environment will bring different working environments and different conditions. Both countries are expected to have differences in terms of business ethics.

The results obtained from this study will be important in the sensemaking of the employees behavior for companies where operating in Turkey and Iran. This is important for the creation of a work team for companies which are operating in both countries. Therefore, it is wondered how employee voices and silence behaviors change according to socio-economic and demographic variables.

The research questions based on the literature and these knowledges are made as follows.

-Do employee voice and silence behaviours
differentiate according to demografic charac-
teristics such as gender, sector, age, education,
marital status, firm size and total working time
at firm for Iran and Turkey participants?

\section{Research Methodology}

\subsection{Data Source and Sample}

The aim of this study was to establish the relationship between participants' demographic characteristics and silence-voice behaviour of employees for Iran and Turkey sample. This demographic characteristics were gender, age, education, marital status, sector, total working time at this firm and firm size.

This study used quantitative research approach and analyzed with statistical procedures and surveyed the employees'voice and silence, to compare differences among Iranian and Turkish participants. Participants were employess who worked in various companies and sectors. Due to time and resource constraints, a convenience sample of Iranian and Turkish employees was recruited. The employees were assured that their participation was strictly voluntary. This study used simple random sampling in selecting respondents that is section from probability sampling techniques. The data collection was completed by the researchers alone. The data collection process was two weeks at different times of the days. The participants might ask any questions during the survey, the researcher was available to answer their questions.

A questionnaire was designed in Turkish and due to the fact that the respondents were Iranian, form was translated into Persian version with an official endorsement from an expert. Disagreements on the transcription were resolved through discussions between the translators. The questionnaire form 
contains 30 employee voice and silence scale items and seven demographic. It took an estimated 10 minutes to complete. The questionnaire constitutes two sections. The first section was designed to collect demographics data. The second section consisted of 30 items for measure employee voice and silence developed by Dyne et al., (2003) and adapted Turkish form from Sarikaya (2013). In the questionnaire 7-point Likert Scale format was used.

Initially, we obtained 160 responses for both samples. After deleting cases with severe missing data, the final sample used in the analysis consisted of 272 responses across groups. The Iran group consisted of 123 respondents. The Turkey group consisted 149 respondents. Each survey was coded with a number and entered into the SPSS program for statistical analysis. All sample responses were entered into a database in SPSS.

Table 1 reports for both sample participants' demographic characteristics grouped by country. According to these results, for Iran sample $37,4 \%$ of respondents were females and $62,6 \%$ were males, $53,7 \%$ were production sector employee, $46,3 \%$ were service sector employee. The age distribution indicated that majority $39 \%$ of respondents were $25-34$ years old and \%30,1 were between 35-44 years old, followed by the other age groups. Of the 123 respondents, $31,7 \%$ had bachelor degree diploma, 20,3\% had master degree, $17,9 \%$ had vocational school degree, $17,1 \%$ had high school degree and 13\% had doctorate degree. The marital status demographics results showed that respondents from both countries were relatively similar in marital status distribution. 59,3\% of Iranian respondents were married and majority the rest were single. $35,8 \%$ respondents' total working time at this firm were 11 years and over, $35 \%$ were $1-5$ years and the rest were 6-10 years. 39,8\% of Iranian employees' firm size were macro, $33,3 \%$ were medium and $26,8 \%$ were micro.

The table also indicated that for Turkey sample $49 \%$ of respondents were females and $51 \%$ were males. Majority of employees were from service sector $(\% 73,2)$. As to the respondents' age, $52,1 \%$ were $25-34$ years old, $26,1 \% 35-44,10,1 \%$ were $45-54$ years old, $9,2 \%$ were $18-24$ and $2,5 \%$ were 55 years and over. According to education results, majority of the respondents $(53,7 \%)$ had bachelor degree, $21,5 \%$ had high school diploma, 11,4\% had master degree and followed by the other education levels. Our findings showed that around $57,7 \%$ of respondents were married and the rest were single. $68,5 \%$ majority of respondents' total working time at this firm were 6-10 years, $18,8 \%$ were $1-5$ years and $12,8 \%$ were 11 years and over. Majority of employees $(71,8 \%)$ were from medium size firm, $33,3 \%$ were medium and $26,8 \%$ were micro.

\subsection{Factor Analysis and Reliability Tests Results}

In order to determine if the measures were metrically invariant across countries, we first checked for the reliability of the measures in each country and secondly we checked the validity of the measures. We checked for the constructs' convergent and discriminant validity through exploratory factor analysis (EFA).

Prior to extraction of the factors related to scales for all sample groups, Kaiser-Meyer-Olkin (KMO) and Bartlett's tests should be applied to examine the appropriateness of the respondent data for exploratory factor analysis. Kaiser-Meyer-Olkin (KMO) must be at least 0.60 , and the higher the better. Bartlett's test must obtain significant value $(p<0.05)$ (Durmuş et al. 2013, p.80). Moreover, Hair et al. (2009) suggest that in the social sciences, where information is often less precise, the researchers should be considered a solution that at least accounts for $50-60 \%$ of the total variance explained. Finally, items' factor loadings should not be less than 0.40 , and these items with a factor loading less than 0.40 should be removed from the analysis (Kalaycl, 2005, p. 321).

First, we checked for the and validity and reliability of the constructs in each sample. An exploratory factor analysis includes the scale items for these employee voice and silence using the Iranian and Turkish sample. So, firstly we ran an EFA with varimax rotation and specified a six factor solution.

Secondly, a similar analysis was conducted using the Turkey sample and due to do fact that two items with a factor load under 0.40 were excluded from scale both Iranian and Turkish sample. Therefore, the results provided initial evidence for discriminant and convergent validity across the constructs in the both samples.

The results of the factor analys were formed as expectedly for both sample. KMO Measure of Sampling adequacy was higher than 0,60. Bartlett's test $p$ value was 0.000 . It indicates that data was appropriate for factor analysis. Also total variance explained was $\% 68,281$ for Iran sample, was $\% 59,291$ for Turkey sample. All total variance explained values which were far beyond the threshold. Table 2 and Table 3 shows factor analysis results for each sample. 
Table 1: Demographic Characteristics of The Samples

\begin{tabular}{|c|c|c|c|c|c|c|c|}
\hline Country & Gender & Frequency & Percent & Country & Sector & Frequency & Percent \\
\hline \multirow{3}{*}{ Iran } & Female & 46 & 37,4 & \multirow{3}{*}{ Iran } & Service & 57 & 46,3 \\
\hline & Male & 77 & 62,6 & & Production & 66 & 53,7 \\
\hline & Total & 123 & 100,0 & & Total & 123 & 100,0 \\
\hline \multirow{3}{*}{ Turkey } & Female & 73 & 49,0 & \multirow{3}{*}{ Turkey } & Service & 109 & 73,2 \\
\hline & Male & 76 & 51,0 & & Production & 40 & 26,8 \\
\hline & Total & 149 & 100,0 & & Total & 149 & 100,0 \\
\hline Country & Age & Frequency & Percent & Country & Education & Frequency & Percent \\
\hline \multirow{6}{*}{ Iran } & $18-24$ & 16 & 13,0 & \multirow{6}{*}{ Iran } & High School & 21 & 17,1 \\
\hline & $25-34$ & 48 & 39,0 & & Vocational School & 22 & 17,9 \\
\hline & $35-44$ & 37 & 30,1 & & Bachelor Degree & 39 & 31,7 \\
\hline & $45-54$ & 15 & 12,2 & & Master & 25 & 20,3 \\
\hline & 55 and over & 7 & 5,7 & & Doctorate & 16 & 13,0 \\
\hline & Total & 123 & 100,0 & & Total & 123 & 100,0 \\
\hline \multirow[t]{6}{*}{ Turkey } & $18-24$ & 11 & 9,2 & \multirow{6}{*}{ Turkey } & High School & 32 & 21,5 \\
\hline & $25-34$ & 62 & 52,1 & & Vocational School & 13 & 8,7 \\
\hline & $35-44$ & 31 & 26,1 & & Bachelor Degree & 80 & 53,7 \\
\hline & $45-54$ & 12 & 10,1 & & Master & 17 & 11,4 \\
\hline & 55 and over & 3 & 2,5 & & Doctorate & 7 & 4,7 \\
\hline & Total & 119 & 100,0 & & Total & 149 & 100,0 \\
\hline Country & Marital Status & Frequency & Percent & Country & $\begin{array}{l}\text { Total Working Time at } \\
\text { Firm }\end{array}$ & Frequency & Percent \\
\hline \multirow{4}{*}{ Iran } & Married & 73 & 59,3 & \multirow{4}{*}{ Iran } & $1-5$ & 43 & 35,0 \\
\hline & Single & 44 & 35,8 & & $6-10$ & 36 & 29,3 \\
\hline & Divorced & 6 & 4,9 & & 11 and over & 44 & 35,8 \\
\hline & Total & 123 & 100,0 & & Total & 123 & 100,0 \\
\hline \multirow{4}{*}{ Turkey } & Married & 86 & 57,7 & \multirow{4}{*}{ Turkey } & $1-5$ & 28 & 18,8 \\
\hline & Single & 58 & 38,9 & & $6-10$ & 102 & 68,5 \\
\hline & Divorced & 5 & 3,4 & & 11 and over & 19 & 12,8 \\
\hline & Total & 149 & 100,0 & & Total & 149 & 100,0 \\
\hline Country & Firm Size & Frequency & Percent & & & & \\
\hline \multirow{4}{*}{ Iran } & Micro & 33 & 26,8 & & & & \\
\hline & Medium & 41 & 33,3 & & & & \\
\hline & Macro & 49 & 39,8 & & & & \\
\hline & Total & 123 & 100,0 & & & & \\
\hline \multirow{4}{*}{ Turkey } & Micro & 23 & 15,4 & & & & \\
\hline & Medium & 107 & 71,8 & & & & \\
\hline & Macro & 19 & 12,8 & & & & \\
\hline & Total & 149 & 100,0 & & & & \\
\hline
\end{tabular}


Table 2: Factor Analysis Test Results for Iranian Sample

\begin{tabular}{lllrr}
\hline \multicolumn{1}{c}{ Factor Name } & Number of Items & $\begin{array}{c}\text { Variance } \\
\text { explained }\end{array}$ & $\begin{array}{c}\text { KMO Test and Bartlett } \\
\text { p value }\end{array}$ \\
\hline \hline \multirow{3}{*}{ Iran Sample } & Acquiscent Silence & 4 & 12,553 \\
& Acquiscent Voice & 5 & 8,509 \\
\cline { 2 - 5 } & Defensive Silence & 5 & 8,012 \\
& Defensive Voice & 4 & 10,313 \\
\cline { 2 - 5 } & Prosocial Silence & 4 & 12,056 & \\
\hline & Prosocial Voice & 5 & 16,837 & 0,845 and 0,00 \\
\hline
\end{tabular}

Table 3: Factor Analysis Test Results for Turkish Sample

\begin{tabular}{llcrl}
\hline \multicolumn{1}{c}{ Factor Name } & Number of Items & $\begin{array}{c}\text { Variance } \\
\text { explained }\end{array}$ & $\begin{array}{c}\text { KMO Test and Bartlett } \\
\text { p value }\end{array}$ \\
\hline \hline \multirow{3}{*}{ Turkey Sample } & Acquiscent Silence & 4 & 10,121 & \\
& Acquiscent Voice & 5 & 6,347 & \\
\cline { 2 - 5 } & Defensive Silence & 5 & 8,022 & \\
& Defensive Voice & 5 & 15,069 & \\
\cline { 2 - 5 } & Prosocial Silence & 4 & 8,415 & \\
& Prosocial Voice & 5 & 11,317 & 0,814 and 0,00 \\
\cline { 2 - 5 } & Total & 28 & 59,291 & \\
\hline
\end{tabular}

The second step was reliability analysis. Item to-total correlations for all items in those scales were above the recommended threshold of 0.50 (Gerbing \& Anderson. 1988). The results shown that the Item to-total correlation value for the Iranian group was 0.45 and we also removed one item. Also, Cronbach Alpha coefficient should be greater than 0.70 (Tavşancıl, 2005). Cronbach alpha values for both sample were more than 0.70 . These results were accepted as reliable. Table 4 shows the reliabilites for these scales for each country respondents.

Table 4: Results of Reliability and Validity Analysis for Each Country

\begin{tabular}{lllc}
\hline & Components & Item & Cronbach Alpha \\
\hline \hline Iran & Acquiscent Silence & 4 &, 901 \\
Turkey & Acquiscent Silence & 4 &, 768 \\
\hline Iran & Acquiscent Voice & 5 &, 710 \\
Turkey & Acquiscent Voice & 5 &, 744 \\
\hline Iran & Defensive Silence & 5 &, 740 \\
Turkey & Defensive Silence & 5 &, 790 \\
\hline Iran & Defensive Voice & 4 &, 737 \\
Turkey & Defensive Voice & 5 &, 786 \\
\hline Iran & Prosocial Silence & 4 &, 819 \\
Turkey & Prosocial Silence & 4 &, 764 \\
\hline Iran & Prosocial Voice & 4 &, 923 \\
Turkey & Prosocial Voice & 4 &, 814 \\
\hline
\end{tabular}

\subsection{Difference Tests Results}

Difference tests are used to determine whether the scale dimensions differ according to some variables. If the normal distribution is provided, parametric tests ( $t$ and ANOVA ( $F$ test)) are used and if normal distribution is not provided, non-parametric tests (Mann Whitney and Kruskall Wallis) are used. Kolmogorov Smirnov or Shapiro Wilks tests are used to determine to normal distribution. The statistical significance value of the tests was greater than 0.05 and the distribution was normal (Field, 2009). The distribution of datas were normal for employee silence and voice on both samples according to Kolmogorov Smirnov test results (P-value $>0.05$ ). Therefore, parametric tests ( $t$ and ANOVA (F test)) were used for both sample. While $t$ test are used to determine difference between two categorical variables, Anova $(\mathrm{F})$ test are used for more than two categorical variables (Büyüköztürk, 2007, p.47). While the $t$ test was statisticly significant, mean values were used to determine diffierence degrees, Anova (F) test was statisticly significant, Post Hoc-Tukey tests were used to determine mean differences.

Analysis of Variance (ANOVA) and t-test tested whether or not there was a significant difference between the means of employee voice and silence between two countries participants. In order to determine the significant difference of employee voice and silence between male and female and the other factors 
two groups, a t-test was employed. The (ANOVA) F-test was carried out to compute the variance within each group for the factors more than two groups.

This was done one sample $t$ test analysis in order to the compare mean of the sum scores for employee voice and silence for each of the two countries: Iran and Turkey.

Table 5 presents the mean values and sample $t$ test results of employee voice by country samples. According to these results there was difference average between country samples and employee voice factors (all $p$ value 0.000 less than 0.05 ). For Iran sample prosocial voice (mean $=3,89$ ) were rated as the highest mean. Acquiscent voice (mean $=2,98$ ) were rated as the second highest mean and defensive voice (mean=2,26) were rated the lowest mean. For Turkey sample prosocial voice (mean $=3,86)$ were rated as the highest mean. Acquiscent voice (mean $=3,26)$ were rated as the second highest mean and defensive voice (mean $=1,79$ )were rated the lowest mean. The one sample t test showed that respondents from both countries were relatively similar in employee voice behaviour but for Iranian participants in all kind of employee voice means were higher than Turkey.

Table 6 indicates the mean values and one sample $t$ test results of employee silence by country samples. According to these results there was difference ave- rage between country samples and employee silence factors (all $p$ value 0.000 less than $p$ value $=0.05$ ). For Iran sample prosocial silence (mean $=4,18)$ were rated as the highest mean. Defensive silence (mean $=2,22$ ) were rated as the second highest mean and acquiscent silence (mean $=2,01$ ) were rated the lowest mean. For Turkey sample prosocial silence (mean $=4,60$ ) were rated as the highest mean. Acquiscent silence (mean $=1,91$ )were rated as the second highest mean and defensive silence (mean=1,63)were rated the lowest mean. The one sample t test reported that for Turkish respondents prosocial silence were higher than Iranian. However, for the other kind of employee silence, Iranian participants' means were higher than Turkish participants.

Table 7 shows the $t$ test results by the gender and sector on employee voice. There were significant differences across gender on only acquiescent voice for Iranian sample and no significant difference across sector. The other types of employee voice were not significant. This indicates that males had more likely to be highly acquiscent voice than females. Also there were significant differences across sector on only prosocial voice for Turkish sample no significant difference across gender. The other types of voice were not significant. This indicates that production sector's participants had more likely to be highly prosocail voice than service sector.

Table 5: Results of Mean of the Sum Comparisons for Employee Voice on Each Country

\begin{tabular}{llrrrr}
\hline Country & & Mean & Std. Deviation & t & P value \\
\hline \multirow{3}{*}{ Iranian } & Acquiscent Voice & 2,98 &, 461 & 71,668 &, 000 \\
& Defensive Voice & 2,26 &, 669 & 37,430 &, 000 \\
& Prosocial Voice & 3,89 &, 941 & 45,877 &, 000 \\
\hline \multirow{3}{*}{ Turkey } & Acquiscent Voice & 3,26 &, 637 & 62,367 &, 000 \\
& Defensive Voice & 1,79 &, 741 & 29,450 &, 000 \\
\hline
\end{tabular}

Table 6: Results of Mean of the Sum Comparisons for Employee Silence on Each Country

\begin{tabular}{llrrrr}
\hline Country & & Mean & Std. Dev. & $\mathrm{t}$ & P value \\
\hline \multirow{4}{*}{ Iranian } & Acquiscent Silence & 2,01 &, 901 & 24,724 &, 000 \\
& Defensive Silence & 2,22 &, 706 & 34,843 &, 000 \\
& Prosocial Silence & 4,18 &, 743 & 62,350 &, 000 \\
\hline \multirow{3}{*}{ Turkey } & Acquiscent Silence & 1,91 &, 820 & 28,440 &, 000 \\
& Defensive Silence & 1,63 &, 656 & 30,429 &, 000 \\
& Prosocial Silence & 4,60 &, 574 & 97,793 &, 000 \\
\hline
\end{tabular}


Table7: Results of Independent Sample t Test by Gender and Sector Differences on Employee Voice

\begin{tabular}{|c|c|c|c|c|c|c|}
\hline Country & & Gender & Mean & Std. Dev. & $\mathrm{t}$ & P value \\
\hline \multirow[t]{2}{*}{ Iranian } & \multirow{2}{*}{$\begin{array}{l}\text { Acquiscent } \\
\text { Voice }\end{array}$} & Female & 2,90 & ,452 & $-1,586$ & ,012 \\
\hline & & Male & 3,03 & ,462 & $-1,596$ & ,011 \\
\hline Country & & Sector & Mean & Std. Dev. & $\mathrm{t}$ & P value \\
\hline \multirow[t]{2}{*}{ Turkey } & Prosocial Voice & Service & 3,76 & ,904 & $-2,222$ & ,028 \\
\hline & & Production & 4,14 & 967 & $-2,153$ & ,035 \\
\hline
\end{tabular}

Table 8 shown the results that there were statically significant differences in prosocial silence depending on gender and sector for Iran sample and no significant difference in acquiscent and defensive silence. This shows that females had more likely to be highly prosocial silence than males. Also service sector's participants had more likely to be highly prosocial silence than production sector. For Turkey sample, there were significant differences in defensive and prosocial silence across gender. Other differences were not significance in acquiscent silence. This indicates that females had more likely to be highly defensive silence than males and males had more likely to be highly prosocial silence than females. Moreover significant differences were found for prosocial silence across sector. Service sector's participants had more likely to be highly prosocial silence than production sector. This result showed that respondents from both countries had relatively similar prosocial silence behaviour across sector.

This table shows the mean differences value, the ANOVA and Post Hoc Tukey test results of defensive voice depending on total working time at this firm and age and the data also revealed a significant difference across age on prosocial voice for Iran sample. Also there were significant differences across firm size and age on defensive voice, and across marital status on prosocial voice for Turkey sample. Remainder demographic factors were not significant in employee voice behaviour. This result shows that Iranian employees who work 1-5 years had more likely to be highly defensive voice than 11 years and over and who work 6-10 years had more likely to be highly defensive voice than 11 years and over. Iranian employees who are 18-24 years old had more likely to be highly defensive voice than $45-$ 54 years. Moreover, Iranian employees who are 18-24 years old had less likely to be highly prosocial voice than the other age groups. For Turkey sample this results indicates that Turkish employees who work at macro business had more likely to be highly defensive voice than at medium business and divorced employees had more likely tobe highly prosocial voice than married employees. Turkish employees who are 18-24 years old had more likely to be highly defensive voice than 25-34, 35-44 and $45-54$ years.

Table 8: Results of Independent Sample t Test by Gender and Sector Differences on Employee Silence

\begin{tabular}{|c|c|c|c|c|c|c|}
\hline Country & & Gender & Mean & Std. Dev. & $\mathrm{t}$ & $P$ value \\
\hline \multirow[t]{2}{*}{ Iranian } & \multirow{2}{*}{$\begin{array}{l}\text { Prosocial } \\
\text { Silence }\end{array}$} & Female & 4,30 &, 482 & 1,414 & ,016 \\
\hline & & Male & 4,10 & ,857 & 1,615 & 011 \\
\hline \multirow[t]{2}{*}{ Turkey } & \multirow{2}{*}{$\begin{array}{l}\text { Defensive } \\
\text { Silence }\end{array}$} & Female & 1,75 & ,723 & 2,085 & ,039 \\
\hline & & Male & 1,53 & ,567 & 2,075 & ,040 \\
\hline \multirow[t]{2}{*}{ Turkey } & \multirow{2}{*}{$\begin{array}{l}\text { Prosocial } \\
\text { Silence }\end{array}$} & Female & 4,52 & 610 & $-1,501$ & ,014 \\
\hline & & Male & 4,66 & ,532 & $-1,497$ & ,014 \\
\hline Country & & Sector & Mean & Std. Dev. & $\mathrm{t}$ & $P$ value \\
\hline \multirow[t]{2}{*}{ Iranian } & \multirow{2}{*}{$\begin{array}{l}\text { Prosocial } \\
\text { Silence }\end{array}$} & Service & 4,28 & ,739 & 1,385 & ,017 \\
\hline & & Production & 4,09 & 741 & 1,386 & ,017 \\
\hline \multirow[t]{2}{*}{ Turkey } & \multirow{2}{*}{$\begin{array}{l}\text { Prosocial } \\
\text { Silence }\end{array}$} & Service & 4,64 &, 520 & 1,398 & ,016 \\
\hline & & Production & 4,49 & 696 & 1,224 & ,023 \\
\hline
\end{tabular}


Table 9: Summary of the Anova-Test Results for the Relationship Between Demographic Factors and Employee Voice

\begin{tabular}{|c|c|c|c|c|c|c|}
\hline Country & Total Working Time in Firm & $\mathrm{F}$ & Sig. & & & Mean Difference \\
\hline \multirow[t]{2}{*}{ Iranian } & \multirow[t]{2}{*}{ Defensive Voice } & \multirow[t]{2}{*}{5,472} & \multirow[t]{2}{*}{,005 } & \multirow{2}{*}{11 and over } & $1-5$ &,$- 401^{*}$ \\
\hline & & & & & $6-10$ &,$- 403^{*}$ \\
\hline Country & Firm Size & $\mathrm{F}$ & Sig. & & & Mean Difference \\
\hline \multirow[t]{2}{*}{ Turkey } & \multirow{2}{*}{ Defensive Voice } & \multirow[t]{2}{*}{4,151} & \multirow[t]{2}{*}{,018 } & \multirow{2}{*}{ Medium } & Micro &,- 197 \\
\hline & & & & & Macro &,$- 503^{*}$ \\
\hline Country & Marital Status & $\mathrm{F}$ & Sig. & & & Mean Difference \\
\hline \multirow[t]{2}{*}{ Turkey } & \multirow[t]{2}{*}{ Prosocial Voice } & \multirow[t]{2}{*}{4,840} & \multirow[t]{2}{*}{,009 } & \multirow{2}{*}{ Divorced } & Married & $1,182^{*}$ \\
\hline & & & & & Single & ,917 \\
\hline Country & Age & $\mathrm{F}$ & Sig. & & & Mean Difference \\
\hline \multirow[t]{4}{*}{ Iranian } & \multirow{4}{*}{ Defensive Voice } & \multirow[t]{4}{*}{2,718} & \multirow[t]{4}{*}{, 033} & \multirow{4}{*}{$18-24$} & $25-34$ &,- 089 \\
\hline & & & & & $35-44$ &, 029 \\
\hline & & & & & $45-54$ &, $396^{*}$ \\
\hline & & & & & 55 and over &, 563 \\
\hline \multirow[t]{4}{*}{ Iranian } & \multirow{4}{*}{ Prosocial Voice } & \multirow[t]{4}{*}{3,835} & \multirow[t]{4}{*}{,006 } & \multirow{4}{*}{$18-24$} & $25-34$ &,$- 839^{*}$ \\
\hline & & & & & $35-44$ &,$- 781^{*}$ \\
\hline & & & & & $45-54$ &,$- 365^{*}$ \\
\hline & & & & & 55 and over & $-1,210^{*}$ \\
\hline \multirow[t]{4}{*}{ Turkey } & \multirow{4}{*}{ Defensive Voice } & \multirow[t]{4}{*}{5,675} & \multirow[t]{4}{*}{,000 } & \multirow{4}{*}{$18-24$} & $25-34$ & $899^{*}$ \\
\hline & & & & & $35-44$ & ,899* \\
\hline & & & & & $45-54$ & $1,089^{*}$ \\
\hline & & & & & 55 and over &,- 015 \\
\hline
\end{tabular}

Table 10: Summary of the Anova-Test Results for the Relationship Between Demographic Factors and Employee Silence

\begin{tabular}{|c|c|c|c|c|c|c|}
\hline Country & Total Working Time at This Firm & $\mathrm{F}$ & Sig. & & & Mean Difference \\
\hline \multirow[t]{2}{*}{ Turkey } & Defensive Silence & 4,190 & 017 & $1-5$ & 6-10 & $452^{*}$ \\
\hline & & & & & 11 and over &,- 331 \\
\hline Country & Education & $\mathrm{F}$ & Sig. & & & Mean Difference \\
\hline \multirow[t]{4}{*}{ Iranian } & Defensive Silence & 3,841 & 006 & High School & Vocational School &, $626^{*}$ \\
\hline & & & & & Bachelor Degree & ,227 \\
\hline & & & & & Master & ,429 \\
\hline & & & & & Doctorate & , $706^{*}$ \\
\hline Country & Firm Size & $\mathrm{F}$ & Sig. & & & Mean Difference \\
\hline \multirow[t]{2}{*}{ Turkey } & Prosocial Silence & 4,152 & 018 & Medium & Micro & $3,358^{*}$ \\
\hline & & & & & Macro & ,173 \\
\hline Country & Marital Status & $\mathrm{F}$ & Sig. & & & Mean Difference \\
\hline \multirow[t]{2}{*}{ Turkey } & Prosocial Silence & 3,885 & 023 & Married & Single & 163 \\
\hline & & & & & Divorced &, $630^{*}$ \\
\hline
\end{tabular}

The results indicated that the mean differences value, the ANOVA and Post Hoc Tukey test results of defensive silence depending on education for Iran sample. Also there were significant differences across total working time at this firm on defensive silence, and the data also revealed a significant difference across firm size and marital status on prosocial silence for Turkey sample. Remainder demographic factors were not significant in employee silence behaviour. This result shows that Iranian employees who had 
high school degree had more likely to be highly defensive voice than vocational school degree and doctorate degree. On the other hand this result shows that Turkish employees who work 1-5 years had more likely to be highly defensive silence than who work 6-10 years. For Turkey sample this results indicates that Turkish employees who work at medium business had more likely to be highly prosocial silence than at micro business and married employees had more likely tobe highly prosocial silence than divorced employees.

\subsection{Conclusion}

When the literature is evaluated, it is seen that the relationship of employee voice and silence behaviours with concepts such as organizational culture, organizational commitment, organizational citizenship behaviour, burnout syndrome, ethical leadership are examined (Zehir \& Erdoğan, 2011; Nikmaram, et al., 2012; Çınar, et al., 2013; Afkhami \& Mehrabanfar, 2015; Çoban \& Sarıkaya, 2016; Sholekar \& Shoghi, 2017; Korkmaz, 2018). It was observed that there were no studies investigating the interrelations between these concepts for both Iran and Turkey with together. In addition, there were no studies that examined the difference according to demographic characteristics. In this study, due to the lack of these studies in the literature for similar studies in Iran and Turkey, comparisons with previous studies could not be done. This result suggests that the study will be important for new studies.

At the end of the study we classified the results which sourced from the comparison of two countries rather than the results for each country under three headlines:

\section{Country based comparison;}

For both country prosocial voice and silence are in front of the other types of voice and silence. Iranian participants' prosocial voice is higher than Turkish participants and prosocial silence in Iran is lower than Turkey.

This result can be explained by Hofstede's study which steresses the cultural dimensions of different countries. Depending on the comparison of cultural dimensions between Iran and Turkey, in both countries the power distance dimension which signs the degree of power within the society or organization are accepted by the less powerful individuals is high. This situation supports the results of country based comparison.

\section{Gender based comparison;}

In Iran, prosocial silence of female employees is higher than male employees. In Turkey, prosocial silence of male employees is higher than female employees.

According to 2016 datas of World Bank, the female labor force participation rate is \%16.24 in Iran and \%30.36 in Turkey. In comparison with Turkey, the number of male employees are higher than female ones in Iran. So female employees may prefer prosocial behaviour against their male colleagues domination in the workplace environment. Additionally, the personality traits which differs depending on genders may effect this result some specific qualifications of the employees such as their high commitment level to organization, their positive and constructive attitudes, cooperative bahaviours with the other members in the organization. Also some organizational factors can be effective on the employees' voice and silence behaviors. One of them can be the management transparency, organizational climate and culture which supports prosocial voice and silence.

\section{Sector based comparison;}

In both country, prosocial silence in service sector is higher than production sector. Customer satisfaction and customer retention have higher priority in service sector rather than production. Therefore in service sector, most of the employees may prefer prosocial silence behaviour to achive these aims so this tendency may lead them to behave in a same manner in the organization.

\section{Comparison depending on total working time in workplace;}

In Iran, defensive voice of the employees who work less than 5 years is higher than the employees who work more than 5 years.

The result of Iranian sample analysis can be expressed by employees commitment level. The less experienced employees who prefer defensive voice behaviour due to their low level of organizational commitment. As a secondary reason, these employees' negative and destructive attitudes and their agressive personality trait can influence this result.

In Turkey, defensive silence of the employees who work less than 5 years is higher than the employees who work more than 5 years.

According to this result, less experienced employees prefer defensive silence behaviour because of some 
worries that they feel. They may think that defensive voice influence their relationship with managers negatively. On the other hand they do not want to be excluded from the groups and seen as incompatible person in workplace environment.

\section{Limitations of the Research}

The findings of the study are limited to the responses to the questionnaire form and it is assumed that the participants answered the questions carefully.

The research is cross sectional and limits to investigate changes in the research over time. The cross-sectional study may have caused the respondents to make an assessment based on their current mood and status, and to disregard the general situation.

The data of 123 Iranian and 149 Turkish participants which can be reached, constitute the other limit of this study. The research datas which collected in one month duration shows the time constraint of the study.

\section{Recommendations for the Future Researches}

In future studies, the research can be applied in specific sectors such as textil, otomobile etc. for both countries.

It is as such regarded that different and more numbers of variables (economic, legal etc.) may be employed.

It can be investigated that the relationship between employees voice or silence behavior with management style, emotional intelligence, business ethics, organizational culture, organizational climate, organizational communication, organizational commitment, organizational justice etc. variables for both countries and comparative analysis are made.

The subject can be taken into consideration with different methodological (qualitative) approaches and contribute to the depth of the related literature. 


\section{REFERENCES}

Adams, J. S. (1965). "Inequity in social exchange”. In L. Berkowitz (Ed.), Advances in experimental social psychology, New York: Academic Press. (2), 267-299.

Afkhami A. M., \& Mehrabanfar, E. (2015). “Organizational Silence, from Roots to Solutions: A Case Study in Iran Petroleum Industry" Iranian Journal of Oil \& Gas Science and Technology, 4(2), 68-83.

Anderson, J.C., Gerbing D.W. (1988) “Structural Equation Modeling in Practice: A Review and Recommended Two - Step Approach" Psychological Bulletin, 103, 411-423.

Ashford, S. J., Sutcliffe, K. M., \& Christianson, M. K. (2009). "Speaking up and speaking out: The leadership dynamics of voice in organizations" In Greenberg, J., \& Edwards, M. S. (Eds.). (2009). Voice and silence in organizations. Emerald Group Publishing, pp. 175-202.

Bagheri, G., Zarei, R., \& Aeen, M. N. (2012). “Organizational silence (basic concepts and its development factors)" Ideal Type of Management, 1(1), 47-58.

Bjerring, J.C., Hansen, J.U., \& Pedersen, N.J.L.L. (2014). "On the rationality of pluralistic ignorance" Synthese, 191 (11), 2445-2470.

Bogosian, R. (2011). “Engaging Organizational Voice: A Phenomenological Study of Employees' Lived Experiences of Silence in Work Group Settings" (Doctoral dissertation, The George Washington University).

Brinsfield, C., Edwards, M., \& Greenberg, J. (2009). “Voice and Silence in Organizations: Historical Review and Current Conceptualizations" In J. Greenberg, M. S. Edwards (Eds.), Voice and Silence in Organizations (3-33). UK: Emerald Group Publishing LTD.

Budd, J. W., Gollan, P. J., \& Wilkinson, A. (2010). “New approaches to employee voice and participation in organizations" Human Relations, 63(3), 303-310.

Büyüköztürk, Ş. (2007). "Sosyal Bilimler İçin Veri Analizi El Kitabı", Ankara, Pegem A Yayıncılık.

Çınar, O., Karcıoğlu, F., \& Alioğulları, Z, D. (2013). "The relationship between organizational silence and organizational citizenship behavior: a survey study in the province of Erzurum, Turkey". 9th International Strategic Management Conference, Procedia-Social and Behavioral Sciences (99), 314-321.

Çoban, H., \& Sarıkaya, M. (2016). "A Research on The Relationship Between Organizational Silence And Burnout", European Scientific Journal. September / SPECIAL/ edition.
Daft, R. L., \& Lane, P. G. (2008). "The leadership experience" (5th ed.). Mason, $\mathrm{OH}$ : SouthWestern Cengage Learning.

Dundon, T. \& Gollan, P.J. “Re-conceptualizing voice in the non-union workplace" International Journal of Human Resource Management, 2007, 18, 1182-98.

Durmuş, B., Yurtkoru, E. S. ve Çinko, M. (2013). "Sosyal Bilimlerde SPSS'le Veri Analizi", Beta Yayıncılık, İstanbul, 5. Baskı.

Dyne, L. V., Ang, S., \& Botero, I. C. (2003). “Conceptualizing employee silence and employee voice as multidimensional constructs" Journal of management studies, 40(6), 1359-1392.

Ehtiyar, R., \& Yanardağ, M. (2008). “Organizational silence: A survey on employees working in a chain hotel" Tourism and Hospitality Management, 14(1), 51-68.

Ellis, J.B., \& Van Dyne, L. (2009). “Voice and silence as observer reactions to defensive voice: Predictions based on communication competence theory" In J. Greenberg \& M. S. Edwards (Eds.), Voice and silence in organizations (pp. 37-61). Bingley, U.K.: Emerald Group.

Field, A. (2009). “Discovering Statistics Using SPSS, Sage Publications", London, 2009, 3rd Edition.

Garner, J. T., \& Garner, L. T. (2011). “Volunteering an opinion: Organizational voice and volunteer retention in nonprofit organizations" Nonprofit and Voluntary Sector Quarterly, 40(5), 813-828.

Gomez, R., Bryson, A., \& Willman, P. (2010). “Voice in the wilderness? The shift from union to non-union voice in Britain". In A. Wilkinson, P. J. Gollan, M. Marchington, \& D. Lewin (Eds.), The Oxford handbook of participation in organizations (pp. 383-406). Oxford: Oxford University Press.

Gorden, W. I. (1988). "Range of employee voice” Employee Responsibilities and Rights Journal, 1(4), 283-299.

Greenberg, Jerald (1987), "A Taxonomy Of Organizational Justice Theories", Academy of Management Review, 1(12), 9-22.

Greenberg, Jerald (1990), “Organizational Justice: Yesterday, Today and Tomorrow", Journal of Management, 16(2), 399-432.

Greenberg, J., \& Edwards, M. S. (Eds.). (2009). “Voice and silence in organizations" Emerald Group Publishing, pp. 175-202. 
Hair, J. F.; Black, W. C.; Babin, B. J.; Anderson, R. E. \& Tatham, R. L. (2009). "Multivariate Data Analysis".7th Edition, Upper Saddle River, NJ: Pearson Prentice Hall.

Harvey, J. B. (1988). "The Abilene paradox: The management of agreement". Organizational Dynamics, 17(1), 17-43.

Hirschman, A. O. (1970). "Exit, voice, and loyalty" Cambridge, MA: Harvard University Press.

Hofstede, G. (2001). “Culture's consequences: Comparing values, behaviours, institutions, and organizations across nations". Thousand Oaks, CA: Sage.

Homans, G. C. (1961). "Social behavior: Its elementary forms". New York: Harcourt, Brace, and World.

Hsiung, H. H. (2012). "Authentic leadership and employee voice behavior: A multi-level psychological process" Journal of business ethics, 107(3), 349-361.

Johnson-Cartee, K. (2005), "News Narratives and News Framing: Constructing Political Reality" Maryland: Rowman and Littlefield.

Kalaycı, Ş. (2005). "SPSS Uygulamalı Çok Değişkenli İstatistik Teknikleri". Ankara: Asil Yayın Dağıtım.

Karacaoğlu, K., \& Cingöz, A. (2008). “Örgütsel Sessizlik. Özdevecioğlu" M. and H. Karadal (Eds.), Örgütsel Davranışta Seçme Konular, Ankara, 155-167.

Kim, J., MacDuffie, J. P., \& Pil, F. K. (2010). “Employee voice and organizational performance: Team versus representative influence" Human Relations, 63(3), 371-394.

Korkmaz, E. (2018). "The Relationship Between Organizational Silence and Allen-Meyer Organizational Commitment Model: A Research In The Health Sector In Turkey", Bilecik Şeyh Edebali Üniversitesi Sosyal Bilimler Enstitüsü Dergisi, 3(1), 200-213.

Launius, R. D. (1998). "The Reorganized Church, the Decade of Decision, and the Abilene Paradox" Dialogue: A Journal of Mormon Thought, 31(1), 47-65.

Lee, G. L., Diefendorff, J. M., Kim, T. Y., \& Bian, L. (2014). "Personality and participative climate: Antecedents of distinct voice behaviors" Human Performance, $27(1), 25-43$.

LePine, J. A., \& Van Dyne, L. (2001). "Voice and cooperative behavior as contrasting forms of contextual performance: Evidence of differential relationships with big five personality characteristics and cognitive ability" Journal of Applied Psychology, 86(2), 326-336.

Menendez, M. G., \& Lucio, M. M. (2014). "Voice across borders: Comparing and explaining the dynamics of participations in a context of change". In A. Wilkinson, J. Donaghey, T. Dundon, \& R. B. Freeman (Eds.), The handbook on employee voice (pp. 381-397). Cheltenham: Edward Elgar.

Moaşa, H. (2013). "Struggling for Organizational Identity: Employee Voice and Silence" Procedia-Social and Behavioral Sciences, 92, 574-581.

Morrison, E.W. \& Milliken, F.J. (2000), "Sounds of Silence” Academy of Management Review, 25, 31-35.

Morrison, E. W. (2014). "Employee voice and silence" The Annual Review of Organizational Psychology and Organizational Behavior, 1(1),173-197.

Miles, S. J., \& Muuka, G. N. (2011). "Employee choice of voice: a new workplace dynamic" Journal of Applied Business Research, 27(4), 91.

Nafei, W. A. (2016). “Organizational Silence: A Barrier to Job Engagement in Successful Organizations" International Business Research, 9(4), 100.

Naus, F., Van Iterson, A., \& Roe, R. (2007). “Organizational cynicism: Extending the exit, voice, loyalty, and neglect model of employees' responses to adverse conditions in the workplace" Human Relations, 60(5), 683-718.

Nikmaram, S., Yamchi, H. G., Shojaii, S., Zahrani, M, A., \& Alvani, S. M. (2012). "Study on Relationship Between Organizational Silence and Commitment in Iran". World Applied Sciences Journal 17(10), 1271-1277

Pacheco, D. C., Moniz, A. I. A., \& Caldeira, S. N. (2015). "Silence in organizations and psychological safety: a literature review" European Scientific Journal, (Special Edition), 293-308.

Perlow, L. A., \& Repenning, N. P. (2009). "The dynamics of silencing conflict" Research in organizational behavior, 29, 195-223.

Pinder, C. C., \& Harlos, K. P. (2001). “Employee silence: Quiescence and acquiescence as responses to perceived injustice" In Research in personnel and human resources management (pp. 331-369). Emerald Group Publishing Limited.

Podsakoff, P. M., MacKenzie, S. B., Paine, J. B., \& Bachrach, D. G. (2000). “Organizational citizenship behaviors: A critical review of the theoretical and empirical literature and suggestions for future research" Journal of management, 26(3), 513-563.

Prentice, D. A., \& Miller, D. T. (1993). “Pluralistic ignorance and alcohol use on campus: some consequences of misperceiving the social norm" Journal of personality and social psychology, 64(2), 243. 
Rezabeygil, S., \& Almasi, D. (2014). "Organizational Silence: A Dangerous Phenomenon in the Way of the Organizational Progress" International Journal of Basic Sciences \& Applied Research, 3, 300-306.

Richard, N. (2003). "Why Do We Remain Silent in the Face of Unethical Behavior?, The Politics of Ethics: Methods for Acting, Learning, and Sometimes Fighting, with Others in Addressing Ethics Problems in Organizational Life". New York: Oxford University Press.

Rusbult, C.E., Farrell, D., Rogers, G. \& Mainous III, A.G. "Impact of exchange variables on exit, voice, loyalty, and neglect: An integrative model of responses to declining job satisfaction" Academy of Management Journal, 1988, 31(3), 599-627.

Sarıkaya, M. (2013). “Karar Verme Süreçleri ve Örgütsel Sessizlik" Master Thesis, University of Pamukkale.

Schechtman, G. (2008). "When Silence speaks louder than words: Computer-mediated communications and perceived ostracism" PhD, Washington State University.

Shelton, J. N., \& Richeson, J. A. (2005). "Intergroup contact and pluralistic ignorance" Journal of personality and social psychology, 88(1), 91.

Shamir, J., \& Shamir, M. (1997). "Pluralistic ignorance across issues and over time: Information cues and biases" Public Opinion Quarterly, 227-260.

Sholekar, S., \& Shoghi, B. (2017). "The Impact of Organizational Culture on Organizational Silence and Voice of Faculty Members of Islamic Azad University in Tehran". Iranian Journal of Management Studies, 10(1), 113-142.

Slade, M. R. (2008). "The adaptive nature of organizational silence: A cybernetic exploration of the hidden factory" (Doctoral dissertation, The George Washington University).

Soltani, E., Liao, Y.Y., Gholami, A. K., \& Iqbal, A. (2017). "Saying it without words: a qualitative study of employee voice in the Iranian building sector", International Journal of Human Resource Management.

Tavşancıl, E. (2005). “Tutumların Ölçülmesi ve SPSS İle Veri Analizi". Ankara: Nobel Basımevi.

Turgut, T., Agun, H. (2016). “The Relationship Between Organizational Justice and Organizational Cynicism The Mediating Role of Psychological Capital and Employee Voice" Işs'te Davranış. 1, 15-26.

Vangel, K. (2011). “Employee responses to job dissatisfaction" In Schmidt Labor Research Center Seminar Series, University of Rhode Island, Kingston, RI, USA. 1-17.

Walster, E., Berscheid, E., \& Walster, G. W. (1973). “New directions in equity Research". Journal of Personality and Social Psychology, 25, 151-176

Wilkinson, A., Dundon, T., \& Marchington, M. (2013). "Employee involvement and voice". In S. Bach \& M. R. Edwards (Eds.), Managing human resources: $\mathrm{Hu}-$ man resource management in transition. Hoboken, NJ: Wiley. 268-288

Wood, G. (2010)."Employee participation in developing and emerging countries". In A. Wilkinson, P. J. Gollan, D. Lewin, \& M. Marchington (Eds.), The Oxford handbook of participation in organizations. Oxford: Oxford University Press. 552-569.

Zanna, M.P. (1996). "Advances in Experimental Social Psychology" Volume 28. California: Academic Press, Inc.

Zehir, C., \& Erdoğan, E. (2011). “The Association between Organizational Silence and Ethical Leadership through Employee Performance", 7th International Strategic Management Conference, Procedia-Social and Behavioral Sciences (24), 1389-1404.

http://data.worldbank.org/indicator/SL.TLF.CACT. FE.ZS?locations=TR (17.5.2017)

http://data.worldbank.org/indicator/SL.TLF.CACT. FE.ZS?locations=IR (17.5.2017) 